\title{
Indigenous in Jackie French's Perspective as a White Author: Unsettling Narratives in Australian Children's Book
}

\author{
Anandayu Suri Ardini \\ Universitas Islam Indonesia \\ 173220501@uii.ac.id
}

\begin{abstract}
Article History:
First Received:

$30 / 11 / 2020$

Final Revision:

$28 / 12 / 2020$

Available online:

$30 / 12 / 2020$

Abstract. How Australian children perceived the image of Indigenous from their readings is highly influenced by the authors. As many Australian children's books are written by White authors, it is important to reveal whether their past and cultural background manifest in the image they built for Indigeneity. This study aims to reveal how Jackie French, a white Australian children's book author, portrayed Indigenous characters and environment in her novels and to find out whether French creates a shift of the images as a form of her tendency to the major culture in Australia. The data were significant textual units from Nanberry Black Brother White novel and were analyzed using Bradford's post-colonial theory of unsettling narrative. The result of this study shows that French deliver a varying degree of Eurocentric mindset in portraying indigenous characters and characterization. It implies that French, as a White-Australian writer still possibly has a colonial mentality who, deliberately or not, positions the Indigenous characters as Others through the focalization of both Non-Indigenous and Indigenous characters themselves. For instance, in Nanberry Black Brother White, it appears that French try to justify whiteness as more civilized and a better race through Nanberry's point of view as an Indigenous child character. It implies that the process of depicting Nanberry, the representation of Aborigines, in the novel is actually a justification for establishing an Eurocentric mindset through the character's narratives, and therefore creates unsettling narratives.
\end{abstract}

Keywords: children's literature, postcolonial, unsettling narratives, white author

\section{http://jos.unsoed.ac.id/index.php/jes}

\section{INTRODUCTION}

When it comes to the existence of indigenous, issues about otherness or the other have been widely discussed in Australia for centuries. In Australian primary schools, there is a textbook entitled Our Society and Others (Oakley, 1985). In a chapter on Aborigines, Indigenous people are depicted through a distant perspective, as if they are part of another society, instead of from the same country. 
It is this distanced viewpoint that makes it difficult for readers to understand the characteristics of Indigenous people. The sense of otherness appears not only in school textbooks but also in children's literature (Bradford et al., n.d.).

The Indigenous were portrayed in children's books based on white authors had in mind. Hancock (1993) adds that how and who the Australians Indigenous are is depicted from the perspective of white settlers instead of by their people. This creates a possibility that author will write distant depictions, where Indigeneity is positioned as others instead of as part of the nation (Clear, 2001). Furthermore, Bradford (2007) states that the imagery crafted by the non-indigenous authors causes the narrative to be unstable. The instability not only can be seen through the storyline but also the language used to build the narrative. Unsettling in this context refer to whether the image really intends to provide a true picture of Aborigines as a part of Australia, or to influence reader's perspective about the otherness of the native tribe. Therefore, further study to investigate this phenomenon in Australian children's literature needs to be conducted.

The first children's text in Australia was an antology of nursery rhyme entitled A Mothers's Offering to Her Children, which was anonymously written in 1841 (Saxby, 1998). Then, in late 1800's to early 1900's, Australian novelist started to write children's stories, such as Ethel Turner and Mary Grant Bruce (Saxby, 2016). In late 1990's, various children's book have been produced by Australian writers, and many studies have also been conducted. Even though several previous studies on children's literature, especially on those produced in settler society, have been widely developed, they mostly focused on intrinsic elements (Babb et al., 2017), gender studies, morals, and genres (Saxby \& Saxby, 2016). Research focusing on post-colonial issues, such as land ownership, Indigenous identity, Indigenous imagery, and Eurocentric narratives is still limited (McGillis, 2000). Most postcolonial literary criticism currently centers on canon literary works written by postcolonial writers. Postcolonial literary criticism of children's books produced by the white author is still not very common. Whereas, children's texts produced in settler society countries such as Australia tend to contain "varying the degree of unease, a sense of being unsettled, or de-settled" or reflect anxiety and instability in the narrative (Bradford, 2007).

The unsettling narrative can be reflected through language. Therefore, Bradford (2007) added that language is the most basic medium used to relate to one another. Besides, language is also a very important tool in which power relations are questioned. The language used in children's books contains various ideologies. In the children's books produced in settler societies, there is a very important and influential concept regarding postcolonial work that constructs ideas and values about colonialism, post-colonial culture, and individual and national identity (Hunt, et al., n.d.; Stephens, n.d.). Unfortunately, as has been mentioned many times before, postcolonial studies of children's literature are still underestimated.

Thus, to further analyze the issues in Australian children's literature, a work by Jeckie French is chosen. Her work is an example of literary works studied in dept through this study. Nanberry Black Brother White is considered as one of French's best-selling work in Australia. It is interesting to figure out how French delivered the image of Indigenous character in her work through her perspective as a white author. To reveal the unsettling narratives that French might create in Nanberry 
Black Brother, post-colonial theory will be used to analyzed the work. This theory is the most suitable to be employed here as post-colonial theory focus on several field such as economic, politic, culture and literature as the effect of colonization happened in the past (Ashcroft, 1998). To be specific, Bradford's theory of unsettling narratives is going to be employed in this research as it is the most relevant theory which specifically focus on postcolonial issue in children's literature.

\section{RESEARCH METHOD}

This study used a textual analysis design. The author collected data from a novel to be analyzed and described descriptively. Before doing the analysis, the first step was to determine the material object to be used as primary data. The primary data in this study were Jackie French's children's novels, Nanberry Black Brother White. Furthermore, from this material object, data related to the depiction of Indigenous people by the white writer were collected. After that, relevant data were classified.

Next, after the data were collected and classified, they were analyzed using Bradford's concept of unsettling narratives in children's literature. The textual analysis required several steps, including searching, collecting, reading, and studying relevant reference books, articles, and journals that support research, and interpreting and analyzing the data. The story focalization in the novel was analyzed and the cultural bias and the mindset shown by these focalizations was identified. The narrative of the novel is considered unsettling if there is a marginalization of Indigenous characterization, despite the inclusive effort of Jackie French to represent the characters in her novel. Finally, the last process in this study was to conclude from the results of the analysis.

\section{RESULT AND DISCUSSION}

\section{Subjectivity and Focalization}

A crucial consideration in the process of representing Indigenous in children's literature is how the point of view and focalization shapes subjectivity and determines the position of the reader in viewing these representations. Focalization is considered very important by Bradford to position the reader parallel to the characters in the text. By Stephens (via Bradford, 2007) this is called textual subjectivity. This means that if the readers have deeply dived in the narrative of the story, it will be challenging to see the implicit embodiment of ideologies into the center character through their narratives.

\section{a. Indigenous Character Focalization}

When a non-native writer developed a focalization from the point of view of an Indigenous character, he must in such a way imagine how these Indigenous characters think, act, judge, and feel (Bradford et al., n.d.). The story or the narrative then becomes unsettling because the author's attempt to present a focalization that represents real aboriginal life presents a tendency to justify the author's Eurocentric mindset. In the novel Nanberry Black Brother White, Jackie French made Nanberry 
one of the narrative centers; thus, it makes the novel unique and interesting to be read. Besides, the focalization of the story is divided into the point of view of four other characters. Among all central characters, Nanberry is the only Indigenous character. This raised the suspicion that French tends to play it safe in creating focalization. With more White figures at the center of the narrative, she can represent Indigenous culture from the outside and through the perspective of the majority culture.

Nanberry was an Australian Indigenous child who came from the Cadigal tribe. Long story short, almost everyone in his group died of an epidemic of chickenpox so he was adopted by Surgeon White. What is interesting to observe from Nanberry's narrative is that there are two different phases in his perspective. The first phase is when he was still living with his family until he fell ill, which was from January 26,1788 , to May 18,1789 . The next phase is when he was adopted by Surgeon White, starting from 18 May 1789 until the end of his life. This is interesting to observe because there are contrasting changes in Nanberry's perspective, especially in the way he sees and interacts with white settlers.

In the storyline. before the epidemic occurred, French created Nanberry's perspective as a Native. Nanberry is depicted to be in awe and amazement at the arrival and appearance of the White people, calling them "white ghosts," and seeing them as ridiculous for not understanding how to live in the wild.

There is a quote from the novel that illustrates the way Indigenous people think about immigrants:

He could see people! Men with white faces, their bodies covered in the skin of strange animals, blue and red and brownish grey. Their voices sounded like human voices, not the wind-whispering of ghosts.

Some of the white ghosts glanced over at the warriors. None bothered to answer the challenge, or even call a greeting. It is as though we are the ghosts, thought Nanberry. As though they expect us to fade away. (French, 2011: 3)

The first paragraph contains Nanberry's astonishment, which is considered to represent the thoughts of all members of his clan towards the arrival of the White immigrants. French describes how a group of people who have lived for thousands of years only with members of their tribe witness the arrival of a group of strangers who are physically and mentally different from them. Then the phrase 'As though they expect us to fade away' indicates negative assumption the natives have for the newcomers.

As mentioned by Brewster (2008) Aborigines, during the era of the First Settlers, saw whiteness, including appearance and habit, as something threatening yet ridiculous. It is because the vast difference between the two tribes created distance and prejudice. Further, in his study, Brewster (2008) discussed how Indigenous writers tend to create humor and defamiliarization of whiteness in their 
works. However, in this research, the focus is quite the opposite of Brewster's study. White authors, in contrast with indigenous writers, created Indigenous character in their works as an appreciation or an inclusive effort to write about both cultures in contemporary children's literature. However, the narrative can be unsettling as the inclusive effort is sometimes shadowed by the author's Eurocentric mindset.

Furthermore, French also described the astonishment of the Indigenous people toward British settlers with a humorous speech style. Through these children's speech styles, the newcomers are seen as a joke rather than a threat to the existence and culture of the Indigenous people. Examples of citations are as follows:

The white ghosts chopped down trees. They built big huts. They lived in the huts all year, until they stank. Their women didn't know how to fish and when they gathered oysters, they threw away the flesh and kept only the shells.

How could people be as stupid as these? When they had captured Colbeemaybe so he could show them how to build canoes-it had been easy for him to escape. (French, 2011: 11)

Among the feelings of astonishment and fear felt by Nanberry, there is also a sense of admiration for what newcomers do and have. One thing that Nanberry admired was the large ship.

Only Nanberry lingered, still peering from behind his tree. He had thought he had made himself part of the sea. But these big canoes conquered the waves like the sea eagle controlled the wind. If only he could ride the waves like that. If only he could slip between the wrinkle at the edge of the sea and sky and see the world beyond the blue horizon. (French, 2011: 13)

French develops Nanberry's character from a child perspective. The child is depicted to be curious and full of wonder. He is amazed and somewhat obsessed with one symbol of civilization brought by the White settlers. In his study, Sambell (2003) mentioned that the ships were one of the most common symbols of colonization. It was the ship that brought British settlers to explore new worlds which they considered exotic and distant; it was the ship that brought imperialism to spread from Europe to many other parts of the world. Marine ships are a symbol of power and knowledge for the nations who created and used them to explore the world (Hunt, et al., n.d.).

Nanberry's admiration which subsequently developed into a kind of obsession with ships creates a justification that the West is indeed superior in power and knowledge compared to the Aborigine. Nanberry's desire to penetrate boundaries, rule the oceans, and explore the world seems to be in line with the principles and habits of nomadic Indigenous people who do not settle in one place. However, his obsession with ships makes the character want more than that. 
Nanberry's narrative as a part of the Cadigal tribe is only conveyed in the first fifty pages of the book. In the later parts of the novel, Nanberry is adopted by a White settler and lives in the way they do. It is a turning point in Nanberry's life and perspective as an Aborigine child.

Since being adopted, his point of view has changed to be a part of the immigrant tribe. During this transition, Nanberry experiences doubt about his identity. This doubt arises because of his fear of living alone without the groups and community systems that support him. One of the examples is:

Booroong muttered, half awake. Arabanoo held her tenderly. He lifted a coolamon of water for her to drink, and stroked her hair. Booroong and Arabanoo were from the same clan, which was why Arabanoo talked to her, not him. Boorong had fourteen summers. She was a woman now, though when she was brought in she had been wearing a bungu skin apron to show she wasn't married yet. Nanberry was nothing to a warrior like Arabanoo-even a captive one-not till he was initiated as a man. (French, 2011:14)

Fear of mortality and loneliness seems to be the reason why Nanberry later accepted his new life in the white community without any significant resistance. At the beginning of his life at Surgeon White's house, he rejected his new name, Andrew, and refused to be considered as a pet. However, as time goes by, Nanberry is accustomed to the new habit and can adapt. He also concluded that a new life as part of the white society was good enough for him. Some of the quotes below show that Nanberry affirms that being part of white settlers is better.

He had seen things these warriors never had. He had ridden in a boat! He had sat on a horse! He knew how to speak the white-ghost-the English-tounge. He could wear boots.

The warriors were strangers, even if they have the same color skin as him.

All at once he knew what he wanted to be now. I will be English, he thought. I will forget the ghosts of Cadigal. I will stay with Father White. I will eat corn and sit on chairs. One day I will go in a big ship with sails. (French, 2011: 85)

Nanberry's viewpoint determined when he had to choose between the Cadigal tribe and his new life as part of the white settlers. Nanberry started to think that his Cadical fellows treated him as a stranger since he was adopted by Surgeon White. This assumption began when the indigenous knights said "We don't talk with little boys like you. Tell the white ghosts to send a man to talk to us. Go and play with the women. "(French, 2011: 85)

In Aborigine culture, knights or grown-up men plays an important role in the survival of the tribe. They are protectors and warriors. The Aborigines believe in a complex kinship system (Cowan, 1992). For them, when an Aborigine was born, he will bear two names: his casual name and his skin name. This skin name shows the 
position of a person in the kinship system. Although each tribe has a varied kinship system, in general, the basic concept is always the same. When the Knights disowned Nanberry, they break the bond of kinship between them.

However, even if the Knights disregard the ancient kinship system by disowning Nanberry, they tried to emphasize hierarchy through their words. Their being as a male leader is above the position of women and children in society. Yet, the existing hierarchical structure in the Aborigine tribe is actually not that simple. The white author appears to be generalizing the Western hierarchical system with the Aboriginal system (Hall, 2018).

The Knights' refusal triggered Nanberry's defensive manner. In his perspective, he felt even greater because he had done many things that the elders in the tribe had never done before. If examined further, it can be assumed that the offensive attitude of the Cadigal tribesmen towards Nanberry is a means used to justify Nanberry's choice of his new life. Because the people of the Cadigal tribe did not accept him back as a member, Nanberry chose to stay with his White family. This is a justification that the old life is a bitter, dark, wild, and unpleasant past while the future that he chooses as part of the White settlers is better in all respects both materially (food, clothing, opportunity to board a ship) or spiritually (knowledge, way of thinking, mastery of language, calm and compassion from new parents).

\section{b. Non-Indigenous Characters Focalization}

Other central figures who became the focalization in Nanberry Black Brother White were Surgeon White, Rachel, and Andrew. Seeing Natives from the eyes of White's characters, Rachel and Andrew will certainly lead to a further understanding of how French conveyed her narrative about Indigenous.

Surgeon White is one of the central figures in the Nanbery story. He is a surgeon who was born and raised in England before being assigned to explore the new world in Australia. White's point of view and narrative throughout the story explicitly explains his dislike for Australia. This one-sided view of the early days of the Australian continent is told by the author through White's dialogue or monologue with himself. He mentions Australia as '... a country and place o forbidding and so hateful as only to merit execration and curses' or in short, it can be interpreted as a place full of hatred and curses. It stands to reason, then, that throughout the narrative Surgeon White is depicted as expressing his reluctance to live in Australia.

During his duty in Australia, Surgeon White adopted Nanberry and tried to educate him in the European way. Changing his name, dressing him with 'proper' clothes, and teaching him how to speak English are some of the efforts that Surgeon White did to change Nanberry. What Surgeon White did resembles the phenomenon of The Stolen Generation decades ago. Between 1900 and 1970, the Australian 
government took Aboriginal children from their parents in their residence to be raised in a Western way (Cowan, 1992). They are taught to speak English, to dress 'properly', to attend school and to think like English people. As a result, the adopted children lost their skill as an Aborigine and their identity as an Indigenous. Through the narratives of Surgeon White's character, readers are led to the understanding that Indigenous can only be equal to the settlers if they act like them and speak their language.

The effort to domesticate some Indigenous people can also be interpreted as an act to manage their fear. Surgeon White's fear was based on several reasons, such as the attacks from the Indigenous people and the helplessness of the British colony in the foreign land. This actually can be referred to as Homi Bhabha's (via Bradford, 2007) concept of hybridity or the resistance of the colonized to the invaders. The colonizers, or the British colony, did not always feel safe when they entered a new area and interacted with the indigenous people. In return for their play of power and occupation, they feared the revenge that Indigenous people might launch at any time.

When viewed using the concept of white imaginings by Bradford (2007), Natives depicted from the perspective of white characters and written by white authors tend to be viewed as orients. Even if it is conveyed in a very subtle way, the colony always gives an impression that the Indigenous people have a more backward civilization.

A similar fear is showed through another character, Rachel when she first met Nanberry. Rachel's concern for Nanberry is reflected in one of her dialogues with Maria.

"...He's a good lad, even if he's a native"

"Does he have a spear?" asked Rachel nervously.

"No! The very idea. You'll get no trouble from him. Made for ships, he is. Just remember that he sits at the table with the Master like a gentleman, and don't expect him to do no servant's work..."

Maria's sentence which says "He's a good lad, even if he's a native" shows the contradiction between being good and being a Native. This statement implies the Natives are not associated with good manners. They kill, make trouble, and live in a barbaric way. Nanberry's fondness for large ships, his obedient attitude, and his routine to sitting with Surgeon White at the dinner table like a gentleman make him deserves the predicate of a good lad in the white settlers' perspective. All of those attitudes refer to European customs and culture.

It appears that these characters, Maria and Rachel, do not want to accept the natives as they are. What the British colony viewed as a great civilization did not necessarily correspond to the values held by Aborigines over the decades (Clear, 
2001). Maria's conversation with Rachel represented the mindset of the majority of European society in the past, who considered their culture to be the most superior.

In contrast to that, the non-indigenous central characters' interaction with other indigenous characters, such as Bennelong, Balloonderry, Booroong, and Colbee is not friendly at all. It results in the negative perspectives the central characters have on them. Therefore, the descriptions of the other indigenous characters are mostly conveyed through Nanberry's perspective.

According to Broome (2001), when Aborigines encountered people who show respect to the land the way they do, they will not react violently. However, as time went on, the natives realized that European citizens, in this case, British convicts, were trying to claim and use their land for economical purposes (Coates, 2004). This awareness ultimately triggered their sense to defend the land they have been protecting and living on. In the story, the majority of the narratives are conveyed from the perspectives of white characters so that readers are directed to see the attacks as a form of violence and crime.

Another interesting point of view is delivered by Andrew White. Andrew is Surgeon White's son and also Nanberry's brother. Andrew's existence refers to the title of the novel, Nanbery Black Brother White. Even though he was the only central character born in Australia, Andrew was educated in the European way.

This novel is closed by a narrative conveyed through the focalization of the adult Andrew. He returned to Australia and looked at this place with great admiration because it had changed significantly. The city looked like a European city with typical European urban planning. Yet, in the last chapter of the novel, Nanberry was not mentioned significantly. It was only told that he is dead and Andrew visited his grave and remembered him as a good older brother.

From this narrative, at least two things can be captured. First, the portrayal of Sydney in 1827 and Andrew's admiration towards it is a justification for British colonization. Aboriginal characters are barely mentioned in the narrative. It reflects that the rapid development of Sydney into a city with European urban standards is somehow the cause of the disappearance and elimination of Indigenous tradition at that time. Second, Nanberry, who remained as a memory for Andrew and was depicted with a tombstone is in stark contrast to the depiction of Rachel and Andrew's life as a wealthy and respected family. This implies that the settlers are the active parties. With the culture they brought from their homeland, they build and develop foreign land. On the contrary, Nanberry, who had chosen to be a sailor, was dead and buried in his tomb and in Andrew's subtle memory. The tomb symbolizes the passivity of the Natives, and that is what the author presented in her novel. They were pushed backward and eroded, and therefore, what remained was only a vague memory in the head of the white character, Andrew. 


\section{The Unseen: Eurocentrism in the Author's Perspective}

French's effort to write a children's story full of cultural and historical values is indeed commendable. However, this discussion proves Bradford's opinion that children's texts produced in settler societies do contain anxiety and instability which, although not immediately visible to the naked eye, are present and are continuously being produced. On the one hand, French wanted to produce texts that contained indigenous characters and values from an egalitarian and equal perspective. But on the other hand, the writing is full of racial stereotypes of the colonial mentality.

In Nanberry Black Brother White, one of the most interesting things to observe is French's narrative pattern which divides the focalizations into five points of view. As a historical novel, this story is written based on a true story that has its source. However, as it is presented and crafted in fiction, the author's perspective plays a very big role in building the readers' perspective on this novel (Hall, 2018).

Among the five focalizations, Nanberry is the only native character with a central point of view. This is interesting because the title used for the novel is 'Nanberry', but the story focused more on the white characters. As a consequence, the narrative tends to favor the major perspectives, or in other words the perspective of nonIndigenous or white characters.

Moreover, there is a paradoxically in the position of Indigenous and nonIndigenous people in this novel. The novel's ending was conveyed through the perspective of Andrew White, Surgeon White's biological son. He describes the rapid development of the Sydney coast from a land of the bush into a modern city. While Andrew describes Sydney as developing into a 'better' place to live, Nanberry's character is said to be dead. It appears that the author presents active and passive opposition. Active is represented by the rapid development of the city, while passive is represented by the death and grave of Nanberry and other Indigenous people (Bradford et al., n.d.).

This explanation is sufficient to prove that the narrative produced by French tends to be unstable and shows a fairly strong Eurocentric perspective. If a broader study is carried out, such a perspective is likely not only found in French novels but also in other works. The history of Australian colonization has made the colonial mentality continue to exist in the attitudes and behavior of the citizen, even until today.

\section{CONCLUSION}

Children's literature, like any other genre of literature, is the mirror of society. One of the most popular children's literature writers in Australia, Jackie French, proved through her writing, Nanberry Black Brother White (2011) that the Eurocentric mindset is still attached to her way of thinking, and thus reflected in her writing. She implied this cultural perspective in the novel through the depiction of Indigenous characters, their environment, and their interactions with nonIndigenous characters, in order to create a friendly children's story about the life of the Indigenous. 
In the novel, it is revealed that French's narrative for the book is intended to justify whiteness as more civilized and a better race through Nanberry's point of view as an Indigenous child character. This finding is a prove that the narrative created by French is actually unstable or unsettling, as it is inconsistence with the prior idea to create an inclusive children's story for Australian young readers.

\section{REFERENCES}

Ashcroft, B. (1998). Key Concepts in Post-Colonial Studies. England: Psychology Press. . (1989). The Empire Writes Back. London: Routledge.

Babb, Y. M., Mcburnie, J., Miller, K. K., May, Y., Mcburnie, J., \& Tracking, K. K. M. (2017). Tracking the environment in Australian children' s literature : the Children 's Book Council of Australia Picture Book of the Year Awards 1955-2014 Tracking the environment in Australian children' s literature: the Awards 1955-2014. Environmental Education Research, 4622(May), 0. https://doi.org/10.1080/13504622.2017.1326020

Bradford, C., Mallan, K., \& Stephens, J. (n.d.). New world orders and the dystopian turn : transforming visions of territoriality and belonging in recent Australian children ' s fiction. October 2014, 37-41. https://doi.org/10.1080/14443050802294091

Bradford, C. (2007). Unsettling Narratives: Postcolonial Readings of Children's Literature. Canada: Wilfrid Laurier University Press.

(2001). Reading Race: Aboriginality in Australian Children's Literature. Australia: Melbourne University Press.

(2000). "Saved by the Word: Textuality and Colonization in Nineteenthcentury Australian Texts for Children," Voices of the Other: Children's Literature and the Postcolonial Context. (Edit. Roderick McGillis). Hal. 89-110.

. (1996). "Centre and Edges: Postcolonial Literary Theory and Australian Picture Books," Writing the Australian Child: Texts and Contexts in Fiction for Children. (Edit. Clare Bradford). Hal. 92-110.

Brewster, A., \& Brewster, A. (2008). Humour and the defamiliarization of whiteness in the short fiction of Australian indigenous writer Alf Taylor Australian indigenous writer Alf Taylor. October 2014, 37-41. https://doi.org/10.1080/17449850802410564

Broome, R. (2001). Aboriginal Australians: Black Responses to White Dominance 17882001. Australia: Allen \& Unwin.

Clear, C. (2001). "The Portrayal of Aboriginal Life in Australian Children's Books," Australian Children's Literature: Finding a Voice. (Edit. Michael Stone).

Cowan, J. G. (1992). The Elements of the Aborigine Tradition. USA: Element, Inc.

Coates, K. S. (2004). A Global History of Indigenous People: Struggle and Survival. Hampshire: Palgrave Macmillan. 
French, J. (2011). Nanberry Black Brother White. Australia: Angus and Robertson.

Hall, M. (2018). The Whiteness of the Bomb : Nuclear Weaponry, Race and the Nation in Australian Indigenous Poetics The Whiteness of the Bomb : Nuclear Weaponry, Race and the Nation in Australian Indigenous Poetics. 2856. https://doi.org/10.1080/20512856.2018.1546649

Hancock, J. (1993). "Aboriginal Voices in The Fat and Juicy Place," Australian Children's Literature: Finding a Voice. (Edit. Michael Stone). 27 March, 1993, page 69-78.

Hunt, P., and Sands, K. (n.d) "The View from the Centre: British Empire and Post-Empire Children's Literature," Voices of the Other: Children's Literature and the Postcolonial Context. (Edit. Roderick McGillis). page. 39-54.

McGillis, R. (2000). Voices of the Other: Children's Literature in the Postcolonial Context. New York: Garland Publishing, Inc.

Oakley, M. (1985). Our Society and Others. Sydney: McGraw Hills.

Sambell, K. (2003). "The Quest for the Perfect Planet: the British Secondary World as Utopia and Dystopia, 1945-1999," Utopian and Dystopian: Writing for Children and Young Adults. (Edit. Carrie Hints dan Elaine Ostry). page. 179-195.

Saxby, M., \& Saxby, M. (2016). Researching Australian children's literature. 9670(June). https://doi.org/10.1080/00049670.2004.10721615

Saxby, M. (1998). Offered to Children: A History of Australian Children's Literature 1841-1941. Australia: Scholastic.

Stephens, J. (n.d.) "Continuity, Fissure, or Dysfunction: From Settler Society to Multicultural Society in Australian Fiction," Voices of the Other: Children's Literature and the Postcolonial Context. (Edit. Roderick McGillis). page. 55-70. 